\title{
Partners in Crime: The Anti-intellectual Complicity between the State and the Universities in Turkey
}

\author{
Aslı Vatansever \\ University of Padova, Department of Political Science, Law, \\ and International Studies \\ aslivtnsvr@gmail.com
}

\begin{abstract}
The ongoing witch-hunt in Turkish universities adds a political dimension to the economic precarization of the academic labour force, and should be seen as part of a wider, distinctly neo-liberal attempt on the part of the state to eradicate rational agency. By eliminating qualified oppositional cadres en masse on false accusations, the government implements a policy of systematic deinstitutionalization in the sphere of intellectual production. The erosion of critical subjectivity via deregulation and precarization has certainly been under way for a while now, albeit in different degrees and with diverse intensity. Yet in Turkey, it found an exceptionally fertile breeding ground due to some historical peculiarities of Turkish society, such as the state-oriented institutionalization process of academic structures and the pervasive anti-intellectualism.

The current war against universities in Turkey is being fought (and apparently won) with the help of academia itself. The universal values of knowledge production are being trampled down by the very institutions that are supposed to be dedicated to the safeguarding of these values. University administrations team up with the state in suppressing opposition by exploiting the economic vulnerability of the academic labour force to silence, intimidate or directly punish critical voices within the universities. The actual significance of the Academics for Peace Petition, originally intended as an attempt to bring peace back to the agenda, lies perhaps rather in the fact that it has surprisingly unveiled this unholy correlation between local circumstances and the dynamics of neo-liberalism.
\end{abstract}

(C) VATANSEVER, 2018 | DOI 10.1163/25430149-00101004

This is an open access article distributed under the terms of the prevailing CC-BY-NC license at the time of publication. 


\section{Keywords}

Turkey - Academics for Peace - anti-intellectualism - university - academic labour precarization

\section{Introduction}

A little more than a year into the publication of the Academics for Peace Petition, on 25 February 2017, I woke up to the news that a young research assistant, Mehmet Fatih Traş, had committed suicide. Mehmet Fatih had been dismissed from his former university and his job applications at other universities had been constantly rejected for being a signatory to the petition. His death, disguised as a suicide, was a murder committed jointly by the Turkish state and universities, and it shall be remembered as the quintessential manifestation of the deep decay within academia in Turkey.

Meanwhile, I stand here as a dismissed and 'decreed' signatory myself, in the cold Berlin winter, trying to plan as far ahead as I can what I am going to do and where I am going to be in the next couple of months. As an exiled academic, I am struggling to find ways to organize opposition inside Turkey - and outside with other exiled signatories - as if we had the slightest idea of how to get organized as a political diaspora. With every statutory decree, the number of dismissals increases, and it seems that all we can talk about these days is whose names are likely to be included in the next round. Amidst this tasteless existence, reduced to a struggle for mere survival, I try to realize how it all came to this in less than a year. My whole life looks like a construction area and, being a sociologist, whose research happens to focus on precarization, I feel like an oncologist who has just diagnosed cancer on herself. So, in order to avoid obsessing over the inescapable misery of the present, I choose to focus on its background in what follows.

"I signed a petition one day and my whole life has changed" has been the motto for most of us for the thirteen months that followed the publication of the Academics for Peace Petition in January 2016 with originally 1,128 signatures. The purpose of this action was to indicate to the government that we bear witness to what has been going on away from the public eye. The Turkish state abandoned the peace process and launched a massive offensive in the Kurdish populated southeastern regions in summer 2015 that resulted in long and debilitating curfew periods and the death of hundreds of civilians. The online petition published by the Academics for Peace Initiative was a symbolic gesture to emphasize the urgency of reopening of interrupted peace talks and to remind the state of its responsibility to provide peace and safety for 
the citizens. Meanwhile, on an emotional level and with the sense of selfentitlement of the intellectual, we wanted to raise awareness about the situation by telling it like it is: a massacre. ${ }^{1}$ Yet, by proclaiming loudly that we would not be a party to the state's crimes against the Kurdish population, we unravelled a series of other interconnected crimes stretching from the unholy alliance between the state and university administrations in cracking down on critical voices to the shadowy or shifting mechanisms of the precarization of the intellectual labour force, legitimized and supported by deeply rooted antiintellectualism within the Turkish society.

To be sure, neither the knotty relationship between the state and the universities nor the immiseration of the academic labour force is a novelty of the era of the Justice and Development party (AKP). Yet, within the last year, there has been a fresh assault of unprecedented scale on the part of the state against the universities. In the wake of the Turkish president Recep Tayyip Erdoğan's defamation of the first 1,128 signatories of the Academics for Peace Petition as 'traitors' and his call on the Council for Higher Education (YÖK) to take action against this 'dark and ignorant band', repercussions have increased, including criminal investigations and university-level disciplinary proceedings against the signatories. This state-led purge in the universities took another dimension in the aftermath of the coup attempt on 15 July 2016. The consequent declaration (and now extension) of the state of emergency provided the government with almost unlimited power to shut down the opposition by lumping together two different cases and labelling all dissidents as potential Gülenists.

The ongoing witch-hunt in the universities adds a political dimension to the hitherto economic precarization of the academic labour force, and should be seen as part of a wider, distinctly neo-liberal attempt on the part of the state to eradicate rational agency. By eliminating qualified oppositional cadres en masse on false accusations, the government is implementing a systematic deinstitutionalization of intellectual production. The erosion of critical subjectivity via deregulation and precarization has certainly been underway everywhere for a while now, albeit in different degrees and with varying intensity. Yet in Turkey, it found an exceptionally fertile breeding ground due to some

1 The word 'massacre' is a contested term in every sense. Apart from the fact that the Turkish state has always been allergic to its use, as the never-ending debates over the massacre against the Armenian population towards the end of the Ottoman rule may indicate, there is also an ongoing dispute even among the signatories of the Academics for Peace Petition over whether it is appropriate to describe the happenings in the Kurdish-populated regions as such. Yet, in my view, only a glimpse into the report published by the Office of the United Nations High Commissioner for Human Rights (2017) on the case would suffice to cast aside all doubts on this subject matter. 
historical peculiarities of Turkish society, such as the state-oriented institutionalization process of academic structures and pervasive anti-intellectualism.

The current war against the universities is being fought (and apparently won) with the help of academia itself. The universal values of knowledge production are being trampled down by the very institutions that are supposed to be dedicated to safeguarding these values. The university administration teams up with the state to suppress opposition by exploiting the economic vulnerability of the academic labour force in order to silence, intimidate or directly punish critical voices within the universities. The actual significance of the Academics for Peace Petition, originally intended as an attempt to bring peace back to the agenda, perhaps lies rather in the fact that it surprisingly unveiled this unholy correlation between the local circumstances and the dynamics of neoliberalism.

\section{The Corrosion of Academic Ethics in Turkish Universities}

The refusal of the Peace Academics to become a party to the state crimes against the Kurdish population eventually led to a wider confrontation with a series of other crimes in Turkey. The consenting silence of some colleagues and the wholehearted obedience of the administrative cadres at the universities to the brutal crackdown on critical thought rank probably as the most sordid of those crimes.

I remember my dismissal from my position of assistant professor in the middle of the spring semester in 2016 as a kind of a relief that came after months of excruciating agony. The 'warnings' - at first subtle, then open - of the rectorate to 'keep my mouth shut' were rounded off with three disciplinary investigations on petition-related grounds throughout the semester. The supposedly friendly advice of my self-described left-wing colleagues to 'at least remain low key on political issues for a while' during the first weeks after the declaration turned into open hostility when I criticized their hypocrisy, and when the dean stopped greeting me, they all followed suit. The unsettling remarks of the security and cleaning staff insinuating that they were monitoring my every move to report it to the rectorate were met with indifference on the part of the head of my division, who, instead of encouraging me to file a complaint, replied humorously in an elder-sisterly fashion that I should 'behave already'. In the meantime, we were receiving news about the dismissals, investigations, cases of workplace bullying and all sorts of harassment against fellow signatories on a daily basis. Being witness to this degree of rottenness not only at my university but also in almost all Turkish universities, accompanied by an unbearable feeling of being constantly violated in the workplace, left most of 
us with a sour taste and a lifelong aversion to institutional forms of academic career. Early-career academics are hit by particularly deep frustration, as the tragic case of Mehmet Fatih Traş demonstrates. The younger generation of academics had an unfortunate career start in neo-liberal times anyway, when the hitherto known forms of job security in academia were already eroding due to the devaluation of intellectual labour, diminishing budgets and increasingly competitive pressures. Thus, the current war on universities in Turkey means the wholesale destruction of an already meagre possibility of pursuing our intellectual desires and making a decent living for most of us.

Already in the first weeks following the publication of the petition, suspensions and terminations started in private and provincial universities. It was not at all a coincidence that the dismissals began first in the small-town universities and low-ranked private universities: it was a very well thought-out strategy to put the public reaction to a test. Since it is commonly accepted that smaller universities in the provinces do not play a prominent role in academia, and the 'second class' private universities often hire and fire their academic staff in batches each semester, no one - not even many fellow signatories - paid much attention. In fact, if the dismissals had remained limited to a few provincial and private universities, most signatories would probably have made peace with them. However, the sudden declaration of the state of emergency and the statutory decrees that led to a massive wave of 'cleansing' in renowned and long-established state universities caused a great stir. As the overall number of dismissed so-called Peace Academics rose to 383 with the statutory decree of 7 February 2017, a sweeping disillusionment with the whole university structure became paramount among signatories. ${ }^{2}$

The most disturbing aspect of this situation is that this academic massacre is taking place with the passive acceptance of the majority of our colleagues and the active involvement of the university administrations. The 'confessions' of the rectors of some renowned state universities of having voluntarily taken the initiative to include Peace Academics alongside alleged Gülenists in the decree lists is just a small but disquieting case in point. ${ }^{3}$ We find ourselves

2 This number was taken from the internal database of the Academics for Peace network at the time of writing and includes all peace academics that were banned from public service by decree laws, dismissed or forced into retirement, as well as the ones who voluntarily resigned as a gesture of non-compliance with the crimes committed by the university administrations (Academics for Peace 2017). Retrieved in April 2017.

3 According to Fundanur Öztürk's (2017) report on ввс Turkey, after the February statutory decree, the rector of Ankara University - which at that time had the highest number of dismissals (eighty-eight) - refused to answer the journalist's questions, whereas the rector of Ege University explicitly said that he 'cannot give any statement contrary to the decisions of Yöк (Council of Higher Education)'. At Marmara University, a relatively high-ranked state 
asking again and again in bafflement how the whole academic environment could be this complicit. At this point, specific individual stories aside, two mutually reinforcing factors stand out.

The first one is rather a specialty of the social and political formation of Turkish society, rooted in the country's state tradition, and in that sense it can be described as a more local, politico-cultural factor. The authoritarian state tradition in Turkey and the organic ties of the universities to the state since their foundation have always impeded critical thought to a certain degree and moulded the majority of academics into a submissive mass of public officials. This has particularly been the case in state universities where the position of the academic is literally linked with state officialdom. Yet given that the socalled foundation universities of the last two decades have been built by cadres from these same state universities and designed as profit-seeking enterprises relying on contingent academic labour, no significant opposition could be expected from their ranks either.

The second factor that has played into the erosion of academic ethics within the universities in Turkey is a global systemic one, stemming from the structural conditions of the academic labour market, and can be related to what Pierre Bourdieu $(2006,88)$ called the 'structural violence of fear'. All faculties at private and foundation universities in Turkey now consist of casual or sessional academic staff, or 'para-academics' as Andrew Whelan $(2015,2)$ calls them. ${ }^{4}$ The existence of a huge reserve army of labour and the constant intimidation by the threat of unemployment make it unlikely for academics to organize as an occupational stratum unless they are valiant enough to pay for adherence to universal academic values with long terms of unemployment.

Apparently, the academic workforce is in no way exempt from what Richard Sennett (1998) aptly calls the 'corrosion of character' to describe the deforming impact of precarious work relations on the worker's personality. The high degree of association with one's work and the illusions of being so dedicated

university in Istanbul, where, including the dismissals with that decree, a total of eighty academics had been laid off, the rector went a step further and confessed bluntly that it was completely the rector's decision, without any external pressure from the Council of Higher Education whatsoever, to terminate the contracts of the Peace Academics at his institution. He even declared that 'the signatories in Marmara University were given the chance to withdraw their signatures, but none of them took it' (italics added), as though forcing the people to deny their true political convictions and opinions was something to brag about.

4 Whelan $(2015,2)$ uses this term to describe the academics who 'are normally paid on an hourly rate under fixed term contracts, commonly of a semester's duration, though they are commonly re-hired every semester, often for a number of years (these are "YIYOs" - "year in, year outs")'. 
to it that one should be able to ignore even practical daily life needs have been dominating the general expectations from an academic long before the neoliberal restructuration of work relations. In fact, the discursive authority of voluntary asceticism make the academic labour force easy prey for neo-liberal mechanisms of exploitation (Gill 2010). The economic casualization and irregularization of the academic labour market serve to aggravate the structural anxiety of losing a hard-obtained job and falling out of the ranks of the small academic labour aristocracy consisting of a few people who somehow - either by chance or by pulling the right strings - managed to get a more or less steady lecturer position. Being condemned to wage slavery in an anarchic labour market, and the constant anxiety over being counted out of it at any time for good, makes it hard to take a rock-solid and consistent ethical stance in the face of the violation of universal academic values. At this point, the nature of academic labour itself, the structural violence of the neo-liberal labour market and the submissiveness of the university to the state converge to create a highly toxic academic environment in Turkey. In this setting, it seems that a certain degree of corruptibility is required to sustain an academic career.

\section{Universities as Agents of the State}

The history of Turkish universities is, in a sense, the history of the state's control over knowledge production, and of partial resistance and, eventually, overall surrender to that control.

The tense relationship between the state and the intellectuals in Turkey has its roots in the incorporation process of the Ottoman-Turkish society into the capitalist world economy in the 19th century. ${ }^{5}$ In an attempt to catch up with the West, and as a response to the challenges of the incorporation process, the

5 What the Ottoman Empire underwent in the course of the nineteenth century has been somewhat unsatisfactorily described as modernization in the developmentalist literature. These state-oriented accounts of Ottoman history usually tend to ignore the far-reaching social transformations in their relations to the overall systemic change in the nineteenthcentury world and concentrate on the state's efforts to politically and militarily cope with the rise of the Western states. However, in a less trivial sense, and assessed in relation to the global economic developments of the age, the nineteenth-century Ottoman reforms were actually political and administrative complementaries of an overall socio-economic transformation. This socio-economic transformation is to be understood within the context of the incorporation of the Ottoman territory as a peripheral part of the capitalist world economy. There is extensive world-systems literature on this subject. Here it should suffice to name a few basics: Reşat Kasaba (1988), Çağlar Keyder (1987) and Şevket Pamuk (1987). 
Ottoman state embarked upon a series of reforms to rebuild its central power in the 19th century. Abandoning the centuries-long practice of devshirme, it set out to establish Western-type educational institutions to develop a modern civil and military bureaucracy, which was to constitute the core of the modern Ottoman intelligentsia. ${ }^{6}$ In this context, the late Ottoman and early Turkish intelligentsia developed as a state cadre primarily concerned with the revival of the central state power in the face of the challenges of Western capitalism and the internal centrifugal tendencies that it unleashed. And, as such, the intellectuals' main function consisted in producing information, rather than knowledge, in the service and to the benefit of the state.

By virtue of the cultural supremacy of a self-proclaimed modernizing mission, the late Ottoman and early Republican intellectuals dismissed the discontent that some of the especially centralizing and authoritarian reforms caused among various strata simply as signs of a categorical hostility towards modernization, supposedly stemming from an inherent backwardness and ignorance of the population. The truth is, no group or individual is ever essentially reactionary or progressive per se and, as in every state policy, there were winners and losers of the centralist modernization project. Yet, what was essentially a class struggle between the newly emerging stratum of rulers and wider segments of the society took the shape of a super-structural antagonism between the allegedly progressive, pro-Western state intellectuals and the 'reactionary' Muslim masses (Kücükömer 1969).

During the nation-state building, the intellectuals' organic ties to the state cadres led them to assume the role of vanguards of the state-led social engineering program. This involved producing pseudo-academic justification and legitimization for the political, cultural and military violence inherent to the process of building a homogeneous nation-state out of a multi-identitarian empire. ${ }^{7}$ As part of a centralist modernization project, the universities in Turkey were founded basically with the aim of creating a group of torchbearers for statist Westernization.

6 Devshirme refers to the traditional Ottoman practice of collecting boys between the ages eight and eighteen, mainly from the Balkan provinces, to raise them as state servants. It was the main and only method of raising civil and military officials during the classical period of the Ottoman Empire until it started to decline in the seventeenth and eighteenth centuries, and was abolished altogether in the nineteenth century.

7 The prime example of Turkish nationalist pseudo-scientific hypotheses is probably the 'Sun Language Theory', which was developed in Turkey in the 1930s. It proposed that all human languages originated from a proto-Turkic primordial language. The founder of the Republic, Mustafa Kemal Atatürk, was an ardent supporter of the Sun Language Theory. 
In that sense, the history of academia in Turkey is the history of paying lip service to the universal intellectual values and of trampling down on them. That history contains many major authoritarian steps on the part of the state to stamp out oppositional, regime-critical intellectuals and the like. In 1933, during the reign of Atatürk, there was the Darülfünun Reform. ${ }^{8}$ In 1948, there was a witch-hunt in the Faculty of History, Languages and Geography of Ankara University during the Inönü government. ${ }^{9}$ Tensions grew between the Democrat Party (DP) government and the dissenting university professors towards the end of the DP rule, whom the Prime Minister Adnan Menderes mocked as the 'black gowned', and there was a rash expulsion of 147 university professors in the wake of the 1960 coup..$^{10}$ After the coup of 12 March 1971, there was a wave of purges against left-oriented professors and students. The Council for Higher Education established after the 1980 coup was subject to

8 Darülfünun is the Ottoman word for the 'House of Sciences'. The academic institution was founded by Abdulhamid II in 1900 in Istanbul. After the proclamation of the Turkish Republic in 1923, Darülfünun remained relatively autonomous for almost ten years, until a clash between its academic staff and the rulers of the young republic, when some of the history professors in Darülfünun dared to criticize the ideologically distorted, highly nationalistic official history theses that were being propagated by the state and strongly supported by Atatürk himself. Thereupon, Darülfünün was shut down by law on 31 August 1933, only to be re-founded the next day as Istanbul University. Darülfünun originally had 114 instructors, of whom approximately 100 were forced to retire. The newly founded Istanbul University that replaced the Darülfünun only had seventy-eight instructors, sixtyfive of whom were German and Austrian scientists who had escaped the Nazi regime (Boratav 2017).

9 In 1947, Pertev Naili Boratav, Niyazi Berkes and Behice Boran, three professors in the Faculty of Languages, History and Geography at Ankara University, were accused of being communists because they had published articles in a left-wing journal. This sparked a series of events, during which the rector of Ankara University was forced to leave his office by a group of ultra-nationalist students. The aforementioned professors were brought to trial in 1948 and Boratav's department was closed down. Although all three were eventually acquitted, Boratav left Turkey for good (Boratav 2017).

Menderes was referring to the protest march of regime-critical university professors in their academic gowns to demonstrate their discontent with the increasingly authoritarian tendencies of the government in spring 1960 . His taunting remark was made around a month before the military coup that was to result in his execution. In the aftermath of the coup, in which the universities had supported the military takeover against the government that they viewed as increasingly undemocratic, some DP-critical professors were expelled from their universities, despite their active support for the regime change. This rather surprising decision of the provisional military government (the National Unity Committee - Milli Birlik Komitesi) spurred reaction from other academics as well as student councils. 
the administrative, academic and political activities within the universities to state supervision. Some seventy (predominantly leftist) academics were expelled under the martial law No. 1402 in 1983, and there were suspensions during the so-called post-modern coup of 28 February $1997 .^{11}$

There has, then, never really been a time when the Turkish academic climate was completely free of the raison d'état. As the above-mentioned incidents demonstrate, the few free minds that could somehow blossom in this toxic academic environment had to pay a heavy price for simply doing what a true intellectual is obliged to do, that is, to tell the truth. Today, the same line of action is at work against the Academics for Peace.

The AKP, although descending from a counter-tradition and representing the historical 'Other' of the Republican elites, inherited the same authoritarian state tradition based on ethnic, cultural and religious homogenization. Thus, albeit in a different form under an openly anti-intellectualist government, the restrictive ordering essence of the state's approach towards intellectual production persists. The memory of the long-term conflict between the oldestablished state-oriented intelligentsia and the 'reactionary' Muslim masses, now embodied in the AKP's constituency, only adds a further vengefulness to the government's overall attitude towards intellectuals, whose educational background leads the AKP to associate them mechanically with the modernist/secularist lineage.

The universities developed from the start as state-oriented institutions and were always subjugated to state authority; critical thinking that could challenge the founding illusions of the predominant national and religious identity was always punished. Yet, to a certain degree, the keenness of the secularist/ modernist oligarchy to preserve a Western-oriented facade prevented a wholesale obliteration of academic standards and structures. Today, however, under an outright anti-intellectualist government, the shine wears off, and the submissive relationship of the universities to the state threatens to result in an indiscriminate annihilation of all intellectual activity per se.

11 The events of 28 February 1997 is popularly called a 'post-modern' coup to refer to the absence of any armed intervention. Despite the Turkish army's famous fondness for military seizures of the state, this time it took control subtly by imposing a forced resignation upon the Islamist prime minister Necmettin Erbakan by virtue of a set of anti-Islamist decisions taken after the 1997 military referendum. A couple of years later, it became known that during this process several non-governmental organizations, intellectuals and media institutions were classified as either Islamist/dangerous or secularist/safe, according to their proximity to the Islamist government or their inclination towards criticism against the hardcore laicism represented by the military, regardless of whether the critique sprung from a liberal democratic or religious conservative point of view. 
According to the political scientist and fellow signatory Barış Ünlü (2016), the fury that the Academics for Peace Petition caused was due to the fact that it represented a break from and a critique of what he calls the 'Turkishness Contract', the founding principle of the Turkish Republic, which was based upon the denial of the systematically violent elimination of the multi-identitarian social fabric. The Turkishness Contract, Ünlü argues, was maintained for a relatively long time not only through crude state violence, but also thanks to the active participation of Turkish academia in fabricating and proliferating ideologically distorted pseudo-scientific knowledge or simply turning a blind eye on state crimes.

Here, once again the clash is evident between the universal meaning of the term 'intellectual' and its interpretation in the Turkish society. The organic historical ties between the state and the intellectual strata in Turkey have deprived the term 'intellectual' of its universal meaning as someone in a constant quest for truth, and reduced it to a mere mouthpiece of the official ideology and state intelligence. Thus, in the truest sense of the word 'intellectual', Turkish state and society as well as academia have always been anti-intellectualist insofar as the main motive of scientific production has predominantly been the confirmation of what is most convenient for the continuity of the state at the expense of the 'truth'.

The mistrustful view from the bottom of intellectuals as a set of alienated parasites living off public benefits finds reciprocity in the state's authoritarian claim of control over the form and content of all academic and intellectual activities from above. Intellectuals are seen as suspect at best, and as an outright threat to national integrity at worst, if they fail to reaffirm the national self-perception. In this case, the quest for truth becomes a subversive activity per se and is conceived as an insult against 'Turkishness', for it violates the basic agreement upon which the Republic was built: never to question the ultimate moral rectitude of the Turk. The signing of the Academics for Peace Petition basically meant signing off from this 'contract of silence' between the universities and the state that was sealed right at the foundation of the Turkish Republic.

The contract of silence certainly did not come from nowhere, nor is it limited to the relationship between the state and the universities. The ambivalent and submissive relationship with authority makes the cowardice, lack of criticism, moral deficiency and obedience a rule among wider strata in Turkey. In the face of the largely arbitrary nature of the rules, instead of openly confronting authority, most people prefer to search for holes and cracks within the system where they can sneak through. This type of collective behaviour, generated by the authoritarian state tradition and related to a tacit presupposition that laws and rules work to the disadvantage of those they are supposed 
to protect, leads to general normlessness, which permeates more or less every aspect of social relations.

Within Turkish academic circles, this tendency to bypass the rules translates into mediocrity in every sense, especially regarding the scientific-academic qualities of the academic. Strict adherence to universal academic values and scientific ethics is usually seen as being 'too uptight', 'making things unnecessarily harder' and, in the latter instance, as a sign of arrogance. Finding a shorter way around is considered a virtue in Turkish society, and it is no different within its academic environment. However, when it comes to scientific production and the maintenance of the administrative structures that are supposed to uphold the ethical and infrastructural foundations of this specific productive activity, finding a way around often means compromising certain academic criteria to a great extent.

The sense of intellectual responsibility suffers the same fate. Historically and institutionally speaking, the occupation of an academic is seen and, for the most part, exercised in Turkey as a form of 'educational officialdom' that reduces the academic to a mere repeater of a scholastically obtained knowhow (Ünsaldı 2016). ${ }^{12}$ The state-oriented preoccupation of the 19th-century Ottoman intellectuals with the urgency of catching up with the West led to the development of an unrefined utilitarian and eclectic approach towards scientific knowledge (Bora 2017). Further reinforced by the state-led form of institutionalization of higher education during the Republican era, this line of scholarly activity became the predominant mode of intellectual production and has persisted well into the present.

Being an 'educational official' does not refer only to an occupational position. It is rather an attitudinal mindset, a specific mode of existence that shapes and reshapes the limits of one's relation with the surrounding world. Salient here is Pierre Bourdieu's (1984) famous distinction between lector and auctor as two different modes of communication, which he associated with orthodoxy and heterodoxy (as embodied in Raymond Picard and Roland Barthes) respectively. As two distinct types of symbolic producers, the lector and the auctor differ with regard to the nature of their products: The symbolic production of the lector is based upon the values of a clerk, a public official, whose frame of mind is marked first and foremost by caution and conformity towards

12 In his short and provocative piece on being a lecturer, Levent Ünsaldı (2016) offers a critical glimpse of the illusion covering the academic who, despite all the pompous verbosity about being dedicated to science and research, is rarely anything more than an instructor delivering precompiled lectures. 
knowledge. Accordingly, and completely in the spirit of a parish beadle, he acts within the scope of his duties and competencies; that is, he passes the knowledge on in the form of piecemeal information without analytically stitching the pieces together. In contrast, the auctor critically and imaginatively engages with knowledge, sees themselves on a par with the original producer and dares to reinterpret the acquired knowledge in a way as to become a creator (Bourdieu 1984, 116-17). The main discrepancy between these two, therefore, cannot be reduced to a mere divergence in the way an academic performs their 'job'. The main difference lies rather in whether one sees the academic activity merely as a job or as a genuine way of communicating with the world in the first place.

Thus, it should not come as a surprise that most of the signatories received 'indecent proposals' from the university administrations, which 'encouraged' us to confess that we did not read the petition attentively, and advised us to withdraw our signatures in order to keep our jobs. As tragic as it was, it became once again clear that in order to survive at a Turkish university, one has either to be so out of one's senses as to sign a political statement without reading it or such a spineless fraud as to lie and disclaim all responsibility for one's own actions - and all this for the sake of keeping a job.

Where even being an academic boils down to nothing more than compliant make-no-waves workerdom, the AKP's dismissive and criminalizing attitude towards critical thinking and Erdoğan's hateful rhetoric on dissident academics should not be deemed an isolated phenomenon that can be explained simply by the dictatorial ambitions of one single person. They are the reflection of the heart and soul of an entire society.

\section{The Unbearable Lightness of Smashing the 'egghead' with Precarity}

On 16 January 2016, Bekir Bozdağ, the minister of justice, was simply summarizing the view of the government - and of the majority of the Turkish society, to be sure - when he argued that 'only the PKK could have written such a declaration'. He continued to imply that people who signed the Academics for Peace Petition without reading it thoroughly should feel free to withdraw their signatures, in which case they would possibly be spared from the penalties the 'conscious' signatories were about to face (Kural 2017).

Bozdağ's statement was not surprising, as it was preceded by similar insinuations in police interrogations as to whether we were "ordered" to sign the declaration by the Executive Council Co-president of the Kurdistan Communities 
Union (KCK) Bese Hozat. ${ }^{13}$ What is characteristic in both Bozdağ's statement and the questions of the police is the a priori assumption that intellectuals cannot have a political opinion of their own, since they are believed to be detached from society to such a degree that they lack the necessary insight. If anything, they could only be utilized by public enemies, since as 'snotty', 'sellout' elites they more often than not take sides with the enemy 'against their own people'.

The real historical grudge, on which this line of argument subsists, came to the fore after Erdoğan's speech to local politicians at the presidential palace on 20 January 2016, when Erdoğan delivered the good news that 'the old Turkey, where a bunch of self-proclaimed elites and rascals who call themselves intellectuals and academics used to run the whole country, has vanished' (Kural 2017). The occasion was not a random opportunity for Erdoğan just to offload his outrage, but rather a conscious juxtaposition of the educational elites as the epitome of a century-long social and political arrogance and the ordinary, 'real' people who had been looked down to for so long by the former. With this and similar speeches, Erdoğan aims at more than just flattering ordinary people by appealing to their rather simple educational and social backgrounds. He is actually promoting a certain concept of society where a lack of education is not only tolerable, but also elevated to a virtue per se.

In an attempt to compensate for the absence of an organic intelligentsia within their ranks, the AKP movement opts for a harsh course of action against the regime-critical intellectuals and responds to arguments with violence (Durgun 2014). The historically conditioned anti-intellectualism of the 'grand right-wing tradition' in Turkey found itself a particularly convenient venue during the neo-liberalization process. The AKP follows a general strategy of marginalization of certain segments of the society that it is unable to co-opt or incorporate (Coşar and Özcan 2011). ${ }^{14}$ This has produced the precarious working conditions in the neo-liberal university to trounce the academic and intellectual establishment.

13 Already during the first few days following the publication of the declaration, house raids, arrests and police interrogations took place in four relatively big cities, three of them in Western Turkey: Kocaeli, Erzurum, Bolu and Bursa. The content of the interrogations were quickly leaked to the press. Thus, on the basis of the experiences of our already detained fellow signatories, we were able to prepare ourselves for such absurd questions in police interrogations.

14 As of 2011, Simten Coşar and Gülden Özcan counted feminism and workers' movements as the two main factions that are categorically oppositional to the AKP's conservative and neo-liberal agenda respectively. In 2015, the AKP expanded its marginalization mechanisms to dissenting academics. 
Economic precarization and political authoritarianism are thus the two sides of the same neo-liberal coin. The structural anxiety over exclusion from the sphere of formal work is further reinforced by the absence (or gradual undermining) of normative standards in the political arena. As Jason Smith wrote in the preface of Berardi's The soul at work,

This organization of work, in which just-in-time production is overseen by a permanently temporary labor force, is mirrored in the form of governance characteristic of democratic imperialism, sustained as it is by appeals to urgency, permanent mobilization, suspension of norms: governance by crisis, rule by exception. It is impossible to separate the spheres of the economy and the political these days. In each case, a managed disorder, the administration of chaos.

BERARDI 2009, 11

In the AKP rule, the deliberate manufacturing of precariousness and insecurity is 'a new form of regulation ... [a] regime, a hegemonic mode of being governed, and governing ourselves' (Butler 2015, vii-xi). As 'an instrument of governing and, at the same time, a basis for capital accumulation that serves social regulation and control', the 'governmental precarization' refers to more than job insecurity or labour market volatility; it signifies a deliberate policy geared towards an all-encompassing 'destabilization of the conduct of life and thus of bodies and modes of subjectivation' (Lorey 2015, 1, 11-13). ${ }^{15}$ Governmental precarization refers to a far-reaching political strategy aimed at creating a vicious circle, in which the economic and political aspects of precariousness become mutually reinforcing. ${ }^{16}$

15 Ultimately, this overarching precarization of the conduct of life can be viewed as a byproduct of the broader tendency that Nancy Fraser (2013, 119-32), following Polanyi, aptly calls 'fictitious commodification'. Fraser uses the term to describe the tendency 'to commodify all the necessary preconditions of commodity production', which turns 'labor, nature and money into objects for sale on "self-regulating" markets', and results in the 'wholesale destabilization of the economic system on the one hand, and of nature and society on the other'.

16 This reciprocity between the economic and political spheres also manifests itself in the rise of a predator type of leader in the political sphere - as the mirror image of the promotion of sociopathic character traits in the economic sphere. The predator mode of leadership, as perfectly exemplified by Erdoğan, derives authority from spreading a sense of constant mobilization and emergency, putting forward unrealistic demands and confusing messages and offering an out-of-nowhere benevolence every once in a while, while 
In the economic sphere, instead of attempting to mitigate the effects of structural instability, the neo-liberal form of governance implements policies to sustain it. The neo-populist rhetoric of the AKP referring to illusory economic growth, supposedly manifest in the construction of giant shopping malls, double highways, new airports and the like, serves to distract the public opinion from what lies beneath all these non-productive extravagances: a huge transfer of the advantages from the public sector to the private sector and the inevitable doom awaiting a rent-based economy. The truth is, however, that there is a highly unstable economic environment in Turkey, fluctuating among capital inflows, financial excesses and successive crises. This structural instability is complemented by labour market (de)regulations aimed at the further flexibilization of labour, and thus, the destabilization of working relations. ${ }^{17}$ Leaving workers ever more in the clutches of capital, neo-liberal employment policies free the state from the responsibility of creating and securing jobs.

In the meanwhile, the neo-liberal state reallocates the energies released by the diminution of the welfare functions to its repressive functions. The neoliberal transformation of governance corresponds to what Bourdieu $(2006,28)$ called 'the reverse development of the state', where the function of service is compromised and replaced by the function of the use of force. Thus, it can be argued that the manufactured state of overarching insecurity gives way to a state of exception (Schinkel 2009, 13-16). ${ }^{18}$ The radical decrease in the number of democratic institutions due to alleged security reasons, i.e. the 'securitization of politics' as it is widely referred to these days, and the equalization

holding the stick of punishment in the back and, thus, blurring the sense of justice and accountability.

17 The Labour Law of 2003 provided 'the legal basis for flexible employment relationships' by paving the way for temporary and insecure jobs. The Employment Package of 2008 diminished the insurance burden that the newly employed women and young workers put on the employers. The National Employment Strategy of 2011 increased flexible forms of employment by defining new temporary forms of employment, such as temporary workers rented by private employment bureaus, teleworking, on-call work, homeworking and job-sharing (see Özden 2014, 165). Görkem Doğan (2014, 188-202) argues that governments in Turkey usually tend to implement neo-liberal policies gradually, instead of applying shock therapies, and the AKP followed suit insofar as it proceeded by gradually precarizing labour since 2007 .

18 Willem Schinkel (2009, 17-18) describes this type of state as a 'social hypochondriac state', considering its obsession with the maintenance of its own existence, and its overemphasis on controlling, monitoring and security to this end. 
of political opposition with treason gradually narrow the sphere of rational debate. ${ }^{19}$

The erosion of rational frames of political debate is particularly evident in the overt double standard with regard to the distribution of political rights and duties. There is an unsettling ambivalence about the scope of state authority that generates a sense of constantly hanging by a thread while exonerating the ruling cadres from all responsibility. ${ }^{20}$ The state enjoys almost unlimited freedom when it comes to controlling and, if it deems necessary, disproportionately punishing citizens' political expressions and actions, yet it cedes to metaphysical forces when it comes to concrete state responsibilities such as the provision of social security and public safety.

Regarding specific abuses of authority in the form of political corruption or misuse of government power, where the AKP's involvement is as plain as a pikestaff, the government invariably plays the card of human fallibility and aggrievedness. ${ }^{21}$ The brutal crackdown on dissidents on the grounds of alleged

19 In his detailed analysis of the AKP's hegemonic project, Ismet Akca (2014, 13-46) draws parallels between the neo-liberal form of government and 'authoritarian statism', or the 'normal form of government' as defined by Poulantzas in 1978 to describe the then emerging mode of governance as a response to the crisis of capitalism. Akca $(2014,17)$ identifies the increase of state control in every aspect of social life, the diminution of formal freedoms, the transfer of power from judiciary to executive branch, the extensive use of decree laws, the factual elimination of the separation of powers and a crisis of representation as the main features of this form of governance.

20 The head of state's explicitly fatalistic statements on social and public security issues on various occasions further reinforce this general sense of precariousness. Two prime examples of this kind of fatalistic mystification of the profane and obscuring the state's involvement in those crimes are the following: Erdoğan's infuriating defence over the Soma mining disaster in 2014, which killed more than 300 mining workers, saying that 'death is inherent to mining' and 'these types of incidents are ordinary things' (Scott 2014); and the former prime minister Ahmet Davutoğlu's ridiculous statement after the Ankara massacre that "We are a state of law. Although we have the names of the potential suicide bombers of ISIS, we can't arrest them before they take action" (Ali 2015).

21 The fallout between the AKP and the Gülen movement surfaced with the corruption scandal in December 2013. The corruption probe implicating some top AKP officials escalated through leaked wiretaps that documented, among others, the involvement of Erdoğan's son Bilal and Erdoğan himself in hoarding illegally obtained money, and consequently led to a reshuffling of the cabinet. The police and prosecutors coordinating the investigation were known as long-term followers of Fethullah Gülen. That was the culmination point in a series of previous frictions signalling a rift between the Gülen movement and the AKP. Soon thereafter the government started to widely refer to a 'state within the state', a 'parallel structure infiltrating state institutions' and Erdoğan himself declared to have 
(yet not at all proven) links to illegal 'terrorist' organizations - although the president makes do with an half-hearted apology for his and his party's former alliance with Fethullah Gülen - is a prime example of this arbitrariness. The shaky claim of having been deceived by a 'parallel structure' nested in the state should apparently suffice to exempt the ruling party now in office for over ten years from all possible accusations without further explanation.

Instead of taking responsibility, the government draws upon irrational arguments and unaccountable reasons when seeking to shift the blame from itself to pass it on to other political actors that seem to be chosen rather randomly as scapegoats. As a typical example of neo-liberal authoritarian governance, the AKP resorts to conservative populism as a political strategy, which relies upon the constant division of society into antagonistic camps and the absolute demonization of one of those camps, depending on the respective circumstances. In accordance with that governmentality, it creates a dichotomous universe, consisting of a highly individualized form of political power personified in a distinguished leader and everyone else, an amalgam group of potential enemies, now including academics. ${ }^{22}$

On the whole, the political and economic measures of precarization coalesce perfectly in the AKP's anti-intellectualist war on universities. In the AKP's Schmittian universe of irreconcilable antagonisms where political opposition is equalized with terrorism, critical intellectuals are the epitome of the ultimate enemy because of their criticism as well as their historically detested position as an educated elite. The neo-liberal employment policies in the domain of academic work relations come in especially handy, for reduced fulltime employment and increased short-term contractual and contingent work provide the power holders the necessary instruments to punish their 'enemies' by condemning them to an occupational and, eventually, existential death.

This type of penalty, a seemingly non-violent, non-corporal punishment in the form of economic vulnerabilization, can in many ways have a more destructive impact than physical forms of punishment on the individual, for it condemns that person to an immediate, and almost unavoidably individual, struggle for survival. The prospect of long-term unemployment deals a serious blow to personal subsistence and well-being. But, more importantly, plunging the actors into individual economic crises also weakens the sense of collectivity,

been deceived by this 'parallel structure'. Erdoğan made the same argument up in the aftermath of the so-called coup attempt on 15 July 2016. See Hurriyet Daily News (2015). which can be explained as the decline of organized forms of making politics and the concomitant rise of the popularity of 'strong personalities'. 
because the urgent need to get out of the misery usually outweighs higher political and ethical aims. And, as heartbreaking as it is, financial hardship poses the danger of depoliticizing any kind of political opposition movement and breaks any line of resistance unless economic demands are the initial source of discontent - and this was certainly not the case in the Academics for Peace Initiative. This explains partly why we found ourselves increasingly forced to concentrate more on strengthening our internal mechanisms of solidarity than on furthering our demands for peace, as the number of lay-offs rocketed. Furthermore, as the relatively high levels of occupational attachment in academia suggests, the exclusion from institutional structures of academic production can also mean losing the sense of purpose and meaning for most of the academics involved. And this combination of economic and existential crises may certainly exhaust the energies not only for active political resistance, but also for rational and critical thinking at all.

\section{Epilogue}

On the night of 7 February 2017, as I was reflecting on this article, I got the news from some fellow exiled signatories that the Turkish state had issued a new statutory decree (No. 686), which included my name. Of 4,464 people that the decree discharged, 115 were Peace Academics. ${ }^{23}$ As absurd as it may sound, the decree featured several Peace Academics who had already resigned or were long dismissed, like myself. The rationale behind it may seem dubious, since one cannot lose a job twice. What this decree does, however, is twist the knife: it bans us from all kinds of public service, while the stigma of being 'decreed' also eliminates any possibility of getting employed in other sectors as well, and cancels our passports for an indefinite period of time. In short, the state compels those currently abroad to choose between exile or starvation, while those who are still in Turkey are simply condemned to the latter. As for the universities, the last vestiges of something remotely comparable to the universal meaning of 'academia' are being swept away, leaving an intellectual wasteland behind, where the mediocre - and only the mediocre - can thrive.

The first thing that came to mind when I received this news was how some of us had been arguing, all throughout the last year, that the universities would have been completely swept clean of us within a year's time. Every once in a while, I remember how the suggestions to quit our jobs as a gesture

23 With that last statutory decree the total number of dismissed Peace Academics since January 2016 rose to over three hundred, with 241 having being 'decreed' after 15 July. 
of collective political action were ridiculed by many as too radical a year ago. There were always fancy alibis disguised as politically sound resolutions not to start a general boycott. At that time, terminations seemed to be hitting the private universities the hardest, and it was believed that the old established state universities would be spared, with only the exception of some rather provincial ones. Alas, the past has passed, and there is no use in agonizing over the lost chances of a better resistance performance. After all, no battle is lost and won forever.

Our view of the current situation oscillates between hope and despair. This constant ebb and flow echoes in the way we ruminate about our quasi-nomadic mode of existence for the time being. The forced uprooting, not only in the spatial but also in the occupational and existential sense, is uncomfortably reminiscent of what Fredric Jameson saw 'at the very heart of any account of ... late capitalism':

a volatilization of temporality, a dissolution of past and future alike, a kind of contemporary imprisonment in the present, ... an existential but also collective loss of historicity in such a way that the future fades away as unthinkable or unimaginable, while the past itself turns into dusty images.

JAMESON 2015, 120

It is true that precarity hampers rational prognoses and hope by making the future completely unpredictable. Nevertheless, we might be able to break through the neo-liberal and destructive forms of individualization by creating new practices of collectivity outside of the already trembling institutions of yesterday.

'This', as Isabell Lorey $(2015,5)$ puts it, might be 'possible when precarization is not perceived and combated solely as a threat, but the entire ensemble of the precarious is taken into consideration and the current domination-securing functions and subjective experiences of precarization are taken as a startingpoint for political struggles'. By formulating the deinstitutionalized mode of occupational existence as a common denominator with other precarious lives and turning it into a locus of political action, new modes of subjectivation can arise from the ruins of the existing structures. Thus, the task consists in transforming the forced individualization of precariousness into the starting point of a collective movement beyond the hitherto known forms of academic establishment and embracing the self-sufficiency that was imposed through exclusion from institutional forms of academic work. After all, the campus, 
traditionally thought of as a bastion of critical thought, proved itself to be a prison. And the price one has to pay to remain there seems certainly higher than to leave.

\section{Acknowledgements}

This article was written during my seven-month fellowship at the LeibnizZentrum Moderner Orient (ZMO) in Berlin between October 2016 and May 2017. I am very much indebted and thankful to Prof. Dr. Ulrike Freitag, the director of the ZMO, and the whole zMO team for kindly offering a fellowship to endangered scholars like me as a gesture of collegial solidarity and for providing a peaceful and supportive working environment.

\section{References}

Academics for Peace (2017), Internal database. https://barisicinakademisyenler.net/ node/314.

Akca, Ismet (2014), 'Hegemonic projects in post-1980 Turkey and the changing forms of authoritarianism. In Ismet Akca, Ahmet Bekmen and Barış Alp Özden (eds.), Turkey reframed: Constituting neoliberal hegemony, pp. 13-46. London: Pluto Press.

Ali, Tariq (2015), 'After Ankara: Why Erdogan and NATo's strategy is in ruins'. Counterpunch, 15 October 2015. www.counterpunch.org/2015/10/15/after-ankara-why-erdo gan-and-natos-strategy-is-in-ruins/.

Bora, Tanıl (2017), Cereyanlar. Türkiye'de Siyasi İdeolojiler. Istanbul: Iletisim.

Boratav, Korkut (2017), 'Üniversite Tasfiyeleri: Gecmisten Bugüne'. Birgün, 19 February 2017. www.birgun.net/haber-detay/universite-tasfiyeleri-gecmisten-bugune-147393. html.

Bourdieu, Pierre (1984), Homo Academicus. Stanford, CA: Stanford University Press.

Bourdieu, Pierre (2006) Karşı Ateşler. Istanbul: YKY.

Butler, Judith (2015), 'Foreword.' In Isabell Lorey, State of insecurity: Government of the precarious. London/New York: Verso.

Cizre, Ümit (2008), 'The Justice and Development Party: Making choices, revisions and reversals interactively'. In Ümit Cizre (ed.), Secular and Islamic politics in Turkey: The making of the Justice and Development Party, pp. 1-14. Abingdon: Routledge.

Coşar, Simten, and Gülden Özcan (2011), 'Neoliberalism and political dissent in Turkey'. Global Research, 29 December 2011. www.globalresearch.ca/neoliberalism-and-po litical-dissent-in-turkey/28396. 
Doğan, Görkem (2014), 'The deradicalisation of organised labour'. In Ismet Akca, Ahmet Bekmen and Barış Alp Özden (eds.), Turkey reframed: Constituting neoliberal hegemony, pp. 188-202. London: Pluto Press.

Durgun, Özgür Duygu (2014), 'Interview with Tanıl Bora: Türkiye’de Kültür Çatışması ve Son 10 Yılda Kültür-Sanat Politikası Part III'. T24, 12 February 2014. http://t24.com .tr/haber/tanil-bora-muhafazakarlar-kultur-sanat-alaninda-iktidar-olamamaktanrahatsiz,25080o.

Fraser, Nancy (2013), 'A triple movement? Parsing the politics of crisis after Polanyi'. New Left Review 81, May-June 2013, 119-32.

Gill, Rosalind (2010), 'Breaking the silence: The hidden injuries of the neoliberal university'. In Róisín Ryan-Flood and Rosalind Gill (eds.), Secrecy and silence in the research process: Feminist Reflections, pp. 245-56. London: Routledge.

Hürriyet Daily News (2015), “We were deceived” Erdoğan says, accusing "parallel structure” of misinformation'. 20 March 2015. http://www.hurriyetdailynews.com/we -were-deceived-erdogan-says-accusing-parallel-structure-of-misinformation.aspx? pageID $=238 \& n I D=79936 \&$ NewsCatID $=338$.

Jameson, Fredric (2015), 'The aesthetics of singularity'. New Left Review 92 (MarchApril): 101-32.

Kasaba, Reşat (1988), The Ottoman Empire and the world economy: The 19th century. Albany, New York: suny Press.

Keyder, Çağlar (1987), State and class in Turkey: A study in capitalist development. London/New York: Verso.

Kücükömer, Idris (1969), Düzenin Yabancılaşması. Istanbul: Ant Yayınları.

Kural, Beyza (2017), 'Haber, Yazı ve Görüntülerle Barış Bildirisi'nin Bir Yılı', Bianet Online Newspaper, 11 January 2017. http://bianet.org/bianet/egitim/182448-haber-yazi -ve-goruntulerle-baris-bildirisi-nin-bir-yili.

Lorey, Isabell (2015), State of insecurity: Government of the precarious. London/New York: Verso.

Office of the United Nations High Commissioner for Human Rights (2017), 'Report on the human rights situation in South-East Turkey: July 2015 to December 2016', February 2017. www.ohchr.org/Documents/Countries/TR/OHCHR_South-East_Turkey Report_10March2017.pdf.

Özden, Barış Alp (2014), 'The transformation of social welfare and politics in Turkey: A successful convergence of neoliberalism and populism'. In Ismet Akca, Ahmet Bekmen and Barış Alp Özden (eds.), Turkey reframed: Constituting neoliberal hegemony, pp. 157-73. London: Pluto Press.

Öztürk, Fundanur (2017), 'Akademisyenleri Ihrac Eden Üniversitelerin Rektörleri Anlatiyor', ввс Turkey, 23 February 2017. www.bbc.com/turkce/haberler-turkiye $-39055^{8} 54$. 
Pamuk, Şevket (1987), The Ottoman Empire and European capitalism, 1820-1913: Trade, investment and production. New York: Cambridge University Press.

Schinkel, Willem (2009), 'Dignitas mon moritur? The state of the state in an age of social hypochondria'. In Willem Schinkel (ed.), Globalization and the state: Sociological perspectives on the state of the state, pp. 1-22. Basingstoke: Palgrave Macmillan.

Scott, Alev (2014), 'Erdoğan's self-defence over Soma's mining disaster was badly misjudged'. The Guardian, 15 May 2014. www.theguardian.com/commentisfree/2014/ may/15/erdogan-turkey-mining-disaster-turkish-prime-minister.

Sennett, Richard (1998), The corrosion of character: The personal consequences of work in the new capitalism. New York/London: W.W. Norton \& Company.

Smith, Jason (2009), 'Preface.' In Franco Berardi, The soul at work: From alienation to autonomy. Los Angeles: Semiotext(e).

Ünlü, Barış (2016), 'BAK [Academics for Peace] declaration, intellectuals and academic freedom', 2 December 2016 (originally published in Ayrıntı Journal, translated by fellow-signatory Simten Coşar). http://gitamerica.blogspot.ca/2016/12/bak-acade mics-for-peace-declaration.html.

Ünsaldı, Levent (2016), “Hocayım Ben!" Duvar No. 23, 5 January 2016. http://duvardergi si.tumblr.com/post/136664927765/hocayım-ben-levent-ünsaldi-duvar-dergisi-sayı.

Whelan, Andrew (2015), 'Academic critique of neoliberal academia', New Series 12(1): 1-23. http://dx.doi.org/10.11157/sites-voli2issiid258. 